\title{
BLIND JUSTICE: AN ANALYSIS OF THE IMPACT OF THE SYMBOLIC LADY JUSTICE IN ADJUDICATION
}

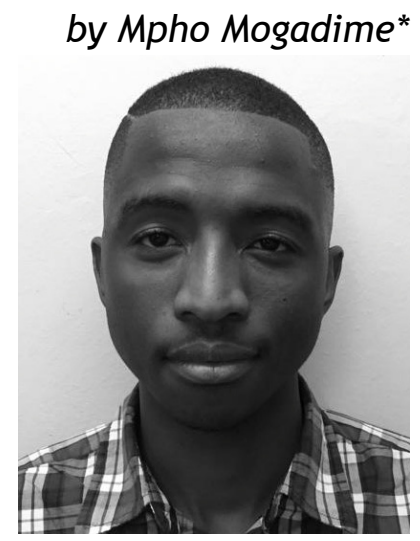

\section{Introduction}

The injustices of South Africa's past have necessitated the enactment of a value orientated approach to law. A value-orientated approach expands law's capacity to substantively contribute towards equalising uneven power relations between people and reconciling the law itself with society through a transformative approach to adjudication. The Constitution $^{1}$ clearly reveals this equalisation and reconciliatory potential through its goal to:

Heal the divisions of the past and establish a society based on democratic values, social justice and fundamental human rights;

Lay the foundations for a democratic and open society in which government is based on the will of the people and every citizen is equally protected by law;

* Third year LLB and General Assistant at the Department of Jurisprudence, University of Pretoria. Debates amongst legal scholars concerning what law is and how it should be interpreted are perpetually ongoing. In South Africa's current constitutional dispensation, legal interpretation through the courts has enjoyed increased attention. This piece is an addition to that debate. It is a critique of the concept of 'justice' as perceived through the age-old image of blindfolded Lady Justice, and it suggests a value oriented approach to adjudication that is not blind - an approach that is able to look at, see, and respond to society's need for justice by utilising the values underlying and/or contained in the Constitution.

1 The Constitution of the Republic of South Africa, 1996. 
Improve the quality of life of all citizens and free the potential of each person. ${ }^{2}$

One of the main challenges to this constitutional goal is how neutrality and objectivity have often been portrayed through the symbol of Lady Justice when it comes to judges and adjudication. ${ }^{3}$ This may have led to an understanding of adjudication that denies the political significance of law and does not allow the space for judges to express their own views where appropriate or to bring valuable insight to their adjudication.

This article serves as an analysis of the depiction of the neutrality and objectivity of judges through the image of Lady Justice. I will investigate whether this depiction is relevant under the current constitutional dispensation, bearing in mind a value-orientated approach to law. Firstly, I will discuss the historical development of the image of Lady Justice with regards to adjudication. Secondly, I will analyse the relevance of Lady Justice in a post-apartheid South African context. Thirdly, I will provide a discussion on the postapartheid contextual meaning of reconciliation and the onus of a value-orientated approach to adjudication that the Constitution has placed on the courts.

\section{The historical development of Lady Justice in adjudication}

The image of Lady Justice, which originated from the ancient Greek goddess Themis, ${ }^{4}$ and also known as the goddess Justitia during the early Roman period, ${ }^{5}$ has often been depicted as a symbol of divine justice with scales in her left-hand for measuring the competing claims brought to her and a sword in her right-hand to punish the offenders of the law. In later developments within the legal community, her image has often been attached to the view of how judges should approach adjudication.

One particular feature is her blindfolded eyes, which supposedly symbolise fairness and equal justice; ${ }^{6}$ that is, a manifestation of formal 'equality'. The notion of formal equality holds that all people

Preamble, the Constitution (n 1).

3 'Neutrality' and 'objectivity' are used synonymously in this article - though there is philosophical discourse on the differences between the two.

4 JA Schmid 'Cover the eyes of Lady Justice: An appeal for double-blind peer reviewing' (2003) 4 EMBO reports 734.

5 A Pulte 'Views from The Cathedral: Blindfolds, colour-blindness and other problems with justice's visual acuity' (2013) The Journal Jurisprudence 399, 420.

6 Schmid (n 4) para 1. 
must be treated equally, and aspects such as gender, religion, and race should be disregarded. ${ }^{7}$

During the early Roman period, judges were familiar with the practice of adjudicating in conformity with the best interests of society, which stemmed from the ius gentium - the law that was based on the principles of equity and good faith. ${ }^{8}$ Roman judges generally had discretion over particular cases, and at times the ius gentium was developed to meet the ever-changing needs of society, so as to remain relevant. Hence, the practice of considering the best interests of society through invoking societal values is not nascent, but dates as far back as the Roman law era.

I am of the view that the influence of formal equality is arguably one of the factors that have played a role in causing a shift from the objective to meet society's need for justice, to an approach that aims to purely interpret the intentions of the Legislature. This approach was known in its earliest form as 'interpretivism or intentionalism'. 9 The perpetuation of intentionalism further contributed to the imagery invoked behind Lady Justice. The main similarities between the idea of intentionalism and that of neutrality and objectivity is how they all depict the attitudes of judges in their approach to adjudication. Intentionalism expects of judges to be disengaged from societal needs, expressing extra-judicial moral reasoning or bringing personal life experiences during the performance of their judicial duties where appropriate - the latter being a practice which is inevitable and sometimes necessary. ${ }^{10}$ Bonthuys correctly identifies this in her article, 'The personal and the judicial: Sex, gender and impartiality', as she opines that: ${ }^{11}$

The image of Justice is blindfolded to prevent her from taking account of the particularities and circumstances of the parties which appear before her and thus to administer justice objectively and neutrally.

Although the perpetuation of Lady Justice might perhaps be rooted in a justified pursuit of fair and equal justice, its primary error lies in the denial of the reality that 'judges are [also] human' and cannot

7 See A Smith 'Equality constitutional adjudication in South Africa' (2014) 14 African Human Rights Law Journal 609, 611.

8 PhJ Thomas et al Historical foundations of South African private law (2000) 216.

9 WE Nelson 'History and neutrality in constitutional adjudication' (1986) 72 Virginia Law Review 1237. According to Nelson, this concept dates back to the 1800 s in American jurisprudence.

10 President of the Republic of South Africa And Others $v$ South African Rugby Football Union And Others 1999 (4) SA 147 (CC) para 42.

11 E Bonthuys 'The personal and the judicial: Sex, gender and impartiality' (2008) 24 South African Journal on Human Rights 239, 253. 
achieve absolute neutrality. ${ }^{12}$ Lady Justice also assumes that parties appearing before a court stand on equal ground. This assumption fails to recognise that people come from different backgrounds, classes and statuses in society, and other circumstances. No two persons are the same, and the factors that differentiate them may play a vital role in the correct administration of justice. Hence, the combination of treating parties before a court in an absolutely equal manner (that is, formal equality), ever without question, and purely applying the intentions of the legislature is unreasonable and at times improper. It leaves justice as undone; that is, the true success of justice thereof is questionable.

The question, then, arises whether Lady Justice is relevant in a post-apartheid constitutional dispensation.

\section{The relevance of Lady Justice in a post- apartheid legal context}

Jeffrey Goldsworthy mentions in his article that, 'Without the support of intentionalism, legal positivism would probably succumb to one of its traditional rivals-either natural law or legal realism'.13 This expression shows how the preservation of intentionalism has successfully perpetuated a culture of legal positivism. ${ }^{14}$ Legal positivism is a school of thought where law is accepted as valid if it has been enacted by the appropriate authority, regardless of whether that law is just. In other words, the moral appeal of an enacted law does not affect its validity. ${ }^{15}$

This is very much related to a formalistic method of interpretation in adjudication, whereby a syllogistic combination of legal rules and facts are used to reach a conclusion. ${ }^{16}$ According to formalist interpretation, the law, which is regarded as separate from morality and politics, is a 'system of self-determining rules that can be applied to the facts of the case in logical fashion'. ${ }^{17}$ This ingenuine conception masks the obvious fact that legislation is enacted as law by subjective human beings who, in the eyes of the formalistic judge, are sacredly consecrated as 'The Legislature' who's laws dare not be

12 South African Commercial Catering And Allied Workers Union And Others v Irvin \& Johnson Ltd (Seafoods Division Fish Processing) 20003 SA 705 (CC) para 13. In this case, Cameron AJ differentiates between neutrality and judicial impartiality, the latter of which refers to the 'quality of open-minded readiness to persuasion - without unfitting adherence to either party or to the Judge's own predilections, preconceptions and personal views'.

13 J Goldsworthy 'Legislative intentions, legislative supremacy, and legal positivism' (2005) 42 San Diego Law Review 493.

14 Goldsworthy (n 13) 495-496.

15 T Humby et al Introduction to law and legal skills in South Africa (2012) 203.

16 Humby (n 15) 203.

17 As above. 
brought into question. Consequently, there is no or little acknowledgement and invocation of underlying values that inform (or should inform) the law within the process of adjudication.

Much to the contrary, however, every law and conduct is required to be in conformity with the Constitution in the current constitutional dispensation. This implies that the Constitution, including its underlying values, informs every law. Cameron $\mathrm{J}$ expressed this view in My Vote Counts NPC v Speaker of the National Assembly and Others (My Vote Counts case), where he stated that:

Far from avoiding constitutional issues whenever possible, the court has emphasised that virtually all issues - including the interpretation and application of legislation and the development and application of the common law are, ultimately, constitutional. This is because the Constitution's rights and values give shape and colour to all law. ${ }^{18}$

The approach referred to in My Vote Counts especially includes judges' methods of interpretation within the process of adjudication. ${ }^{19} \mathrm{~A}$ formalistic approach to adjudication inspired by Lady Justice and perpetuated by legal positivistic thought fails to show its relevance within the current constitutional dispensation, in that it manifestly proves to be incompatible with the value-orientated approach inspired by the Constitution. It fails to invoke the underlying values of the law in its approach, whether to merely interpret the law, or to develop it, or to even challenge it.

\section{The meaning of reconciliation through adjudication in the current constitutional dispensation}

Apartheid South Africa, often described as a 'rights pariah', with a 'wicked system of law', 20 was generally characterised by a form of adjudication that was formalistic in its approach. This approach was often justified by judges claiming to follow the (subjective) intention of the Legislature, under a system of parliamentary sovereignty. The judicial system of apartheid, through its disengagement, was ineffective in administrating substantive justice, which is informed by a substantive reasoning that entails taking the responsibility to invoke (or challenge where necessary) the 'underlying principles that inform laws themselves'.21

My Vote Counts NPC v Speaker of the National Assembly and Others 2016 (1) SA 132 (CC) paras 51.

19 Secs 2 and 39(2) of the Constitution of the Republic of South Africa, 1996.

20 Smith (n 7) 610.

21 P Langa 'Transformative constitutionalism' (2006) 3 Stellenbosch Law Review 351, 357. 
South Africa's unique past has created the need for a unique definition and goal of reconciliation. In a post-apartheid South African context, the main focus of reconciliation is not merely to 'harmonise' society, which would alone bare superficial results; ${ }^{22}$ but it is to constantly define a society that acknowledges the injustices of its past and collaborates in taking the responsibility to redress those injustices, in order to form a South Africa based on freedom, human dignity, and substantive equality. Most importantly, a South Africa that continually engages with change, guided by the values that underlie the Constitution and subjecting the written document itself to any higher demands of justice where necessary. The former Chief Justice Pius Langa referred to this process as 'transformative constitutionalism', whereby there is a:

... perspective that sees the Constitution as ... transformative ... because it envisions a society that will always be open to change and contestation, a society that will always be defined by transformation. ${ }^{23}$

The constitutional goal of reconciliation should be seen as a mandate that creates an onus on the courts to invoke constitutional values in their methods of interpretation and adjudication, ${ }^{24}$ which will help cultivate a legal culture of reconciliation. In Matiso $v$ The Commanding Officer, Port Elizabeth Prison, Fronneman J held that: ${ }^{25}$

The interpretative notion of ascertaining 'the intention of the Legislature' does not apply in a system of judicial review based on the supremacy of the Constitution...The purpose now is to test legislation...against the values and principles imposed by the Constitution.

In fact, this imperative responsibility further necessitates an addition to the cornerstones of adjudication in a post-apartheid legal context - 'transformative adjudication'. ${ }^{26}$ Transformative adjudication is a form of adjudication that allows judges to search for substantive justice by reconciling society with the values enshrined in the Constitution. ${ }^{27}$ It should be noted that transformative adjudication as an 'addition' is not an autonomous principle on its own, but rather a tool that enhances the very core of independence and impartiality as the fundamental cornerstones of adjudication, ${ }^{28}$ while at the same time still respecting and upholding the independent and impartial

22 N Valji 'Race and reconciliation in a post-TRC South Africa' (2004) Ten years of democracy in Southern Africa (available at http://www.csvr.org.za/archive/ docs/racism/raceandreconciliation.pdf).

23 Langa (n 21) 354

24 My Vote Counts NPC (n 18). In this regard, the constitution clearly stipulates that, '... obligations imposed by it must be fulfilled'.

25 Matiso and Others $v$ Commanding Officer, Port Elizabeth Prison, and Another 19944 SA 592, 597.

26 D Moseneke 'Transformative adjudication' (2002) 18 South African Journal on Human Rights 309

27 Moseneke (n 26) 315

28 Humby (n 15) 203. 
discretion that judges have to apply in the performance of their judicial duties. This approach, therefore, acknowledges that law cannot entirely be separated from politics. ${ }^{29}$ Rather, both law and politics should be seen as performing important roles in the activity of creating a truly democratic society; as opposed to the perspective that views law and politics as entities that are in opposition to each other.

The pursuit of reconciliation under the Constitution also facilitates the achievement of one of the major challenges to transformation - access to justice. ${ }^{30}$ In this regard, Sibusiso Zikode, who brings a view 'from below', which is the perspective of the poor and marginalised regarding the substantive law itself, access to the law, and the power of the poor, ${ }^{31}$ propagates in his article the idea that there needs to be reconciliation in the way the law confronts existing power relations, through a substantive application of the rule of law. ${ }^{32}$ This will in succession contribute towards achieving the constitutional objective of access to justice through the courts, ${ }^{33}$ which can be seen as one of the fundamental pillars that contribute towards the advancement of the wider constitutional goal of reconciliation.

\section{Concluding thoughts}

The view of the neutrality and objectivity of judges through the image of Lady Justice ultimately hinders access to justice, in that it incorrectly deems all parties before a court to be absolutely equal having equal power or standing on equal positions. If there is no substantive access to justice or substantive equality, there cannot be a proper facilitation of reconciliation. Consequently, the need arises for the law and its administrators to align themselves with the values underlying the Constitution, so as to advance the interests of justice.

Therefore, the symbol of Blind Lady Justice and especially its role as the foundation that has for a long time informed the depiction of the neutrality and objectivity of judges, which perpetuates a culture

29 Langa (n 21) 353. 'This approach to adjudication requires an acceptance of the politics of law'.

30 Langa (n 21) 355.

31 S Zikode 'Poor people's movements and the law' (2011) Conference on Social Movements and the Law (available at http: / /abahlali.org/node/8551/).

32 G O'Donnell 'Why the rule of law matters' (2004) 15 Journal of Democracy 32. In addition, the rule of law should not be seen in light of formal equality, but as a tool that contributes to building a truly democratic society, when applied substantively.

33 Sec 34 of the Constitution of the Republic of South Africa, 1996. Zikode (n 31): 'We want a society where everyone is treated as equal before the law and everyone has the same ability to access the legal system'. 
of blindness towards issues of society, is irrelevant in the current constitutional dispensation. 